\title{
Work in the Twenty-First Century and the Relevance of the Theory of Value*
}

\author{
Fabiane S. Previtali1,2, Cílson César Fagiani ${ }^{3}$ \\ ${ }^{1}$ Federal University of Uberlândia (UFU), Uberlândia, Brazil \\ ${ }^{2}$ Institute of Contemporary History, New University of Lisbon (IHC/UNL), Lisbon, Portugal \\ ${ }^{3}$ University of Uberaba (UNIUBE), Uberaba, Brazil \\ Email: fabiane.previtali@gmail.com,cilsoncf@gmail.com
}

How to cite this paper: Previtali, F. S., \& Fagiani, C. C. (2017). Work in the Twenty-First Century and the Relevance of the Theory of Value. Advances in Historical Studies, 6, 95-103.

https://doi.org/10.4236/ahs.2017.63007

Received: March 7, 2017

Accepted: September 9, 2017

Published: September 12, 2017

Copyright (๑) 2017 by authors and Scientific Research Publishing Inc. This work is licensed under the Creative Commons Attribution International License (CC BY 4.0).

http://creativecommons.org/licenses/by/4.0/

\begin{abstract}
This article is a review about the book of Ricardo Antunes, The Meanings of Work: Essay on the Affirmation and Negation of Work that has been released in United States (Haymarker books, 2013), United Kingdom (Brill Books, 2013) and India (Akkar Books, 2013). The author, Ricardo Antunes, is an internationally renowned scholar in the field of sociology of work with several publications in Argentina, France, India, Italy, Portugal, Spain, United Kingdom and United States. The author, Ricardo Antunes, is an internationally renowned scholar in the field of sociology of work with several publications in Argentina, France, India, Italy, Portugal, Spain, United Kingdom and United States. In the book, originally published in 1999 by Boitempo Editorial, Sao Paulo/Brazil, after his research conducted in 1999 at the University of Sussex, under the supervision of István Mészáros, Antunes starts with rigorous analysis of the increasingly heterogeneous and multifaceted configuration of the working class as well as the overlaps between productive and unproductive, material and immaterial labour, to restore and complicate the thesis of the centrality of labour and its importance in human sociability.
\end{abstract}

\section{Keywords}

Work, Labour Force, Capitalism

\section{Introduction}

Theory of flexible accumulation (Harvey, 1992, 2011) brought profound changes to the world of work, among others: huge structural unemployment, increasing

${ }^{*}$ Review: The Meanings of Work: Essay on the Affirmation and Negation of Work, Ricardo Antunes (Translated by Elizabeth Molinari).

Brill Books/Historical Materialism Book Series, Vol. 43, Leiden/ Boston, 2013, 235 p. (Published also by Haymarket Books, Chicago, 2013, IL., 248 p. and AAKAR Books, 2014, Delhi, 2014, 248 p.). 
number of workers facing job instability and hyper-exploitation, all this result of social changes, oriented to production of goods and capital appreciation. Taylorism-Fordism accumulation crisis started in second half of decade of 1970, compelled companies to find a more complex, heterogeneous and multi-functional workforce, to be exploited in more intense and sophisticated way by capital (Antunes, 2013). Therefore, productive restructuration process is really nothing more than capital restructuration, to grant its expansion and accumulation. In every step taken to introduce technical and/or organizational innovations, there is an opportunity to overcome ways of resisting labour exploitation controls (Thompson, 2010; Milkman \& Luce, 2013; Carter et al., 2014). More and more, companies benefit from neoliberal work deregulation to modify relations with working class via intensifying flexibilization processes, including such practices as outsourcing and subcontracting, temporary and group work and inflicting heavy defeats to trade-union movement born under Taylor-ford practices. For Harvey (2011: p. 16), “[...] neoliberalism legitimates draconian practices aiming to restore and consolidate capitalist class power".

Taking this into account, present paper will analyze the book of Ricardo Antunes, The Meanings of Work: Essay on the Affirmation and Negation of Work has been released in United States (Haymarker books, 2013), United Kingdom (Brill Books, 2013) and India (Akkar Books, 2013).

\section{The Meanings of Work and the Relevance the Theory of Value}

The author, Ricardo Antunes, is an internationally renowned scholar in the field of sociology of work with several publications in Argentina, France, India, Italy, Portugal, Spain, United Kingdom and United States.

In the original book, originally published in 1999 by Boitempo Editorial, São Paulo/Brazil, after his research conducted in 1999 at the University of Sussex, under the supervision of István Mészáros, Antunes starts with rigorous analysis of the increasingly heterogenous and multifaceted configuration of the working class as well as the overlaps between productive and unproductive, material and immaterial labour, to restore and complicate the thesis of the centrality of labour and its importance in human sociability. The author argues for the ontological significance of work as an essential element of human existence.

The book is structured in eleven chapters, in which Antunes argues vigorously about the centrality of work in the contemporary world, both at a theoretical level, in so far as it is an explanatory category of human existence, and at an empirical level, of praxis, which involves societal transformation with a concomitant change in the proletariat's material activity, consciousness, and social relations.

The central thesis of the book is that, despite the crisis established in capitalist society, it is possible to argue in favor of "[...] centrality of the category of work

in contemporary societal formation, against the theoretical deconstruction 
which was held in recent years" (p. 13). Antunes explicitly opposes Habermas's theory, which affirms the preponderancies of science and technology in the social relation in detriment of the work as the main productive force in contemporary society.

Leaning from Marx, Lukács and Mészáros, among others, the author argues that, to the extent that the capital needs living labour to breed, it is wrong to say that a capitalist society without exploitation of labour and founded on the preponderance of science as the main productive force is possible. For Antunes, one thing is capital's need to reduce its variable dimension and increase the constant part; another thing is to realise that, as the living labour is eliminated, capital can continue to reproduce. The author is emphatic in stating that "[...] The abstract labour elimination thesis does not find theoretical and empirical support for its sustenance in the advanced capitalist countries like the US, Japan, Germany, let al.one the so-called Third World countries" (p. 122).

Antunes (2013) corroborates with Marx for whom value is not a natural attribute of commodities, but a social relation that is materialised in them. Despite taking a variety of forms, the act of working is always a productive expenditure of the mind, muscle and human nerves. Work is therefore an intrinsic capacity of human beings who realise themselves by its action. It is concrete labour, endowed with specific skills and qualifications. In this sense, Braverman (1998) argues that over the course of history, knowledge has been expropriated from the working class and concentrated in the hands of property holders. Under capitalist relations of production, the means used by capital to further exploit workers, gain control over them and increase their productivity has been the technical division of labour, which emphasises the division between manual and intellectual work. In this process, only a small portion of the population has access to the conditions that make it possible to understand the entire process of social production. This comprehensive knowledge is restricted to those who are destined for command and control, perpetuating the cycle of exploitation.

Antunes (2013) argues the relation of production and exchange in capitalism abstracts the concrete character of labour. Value is created by this accumulation of human labour abstracted from its concreteness, based on the assumption that work is performed in an average, socially necessary, time, under normal production conditions, with an average degree of skill and intensity of labour. The value of commodities therefore changes in accordance with the productivity of labour, which depends mainly on the technical means of production and the workers' skill in operating it.

For Previtali \& Fagiani (2015), capital increases surplus value through a continuing process of change both in the means of production and in methods of labour organisation through the application of technology. These changes in turn reduce the value of the commodity and of labour power. Each individual capitalist is stimulated to reduce the labour time of the workforce (that is the cheapening of commodities) by competition from other capitalists. Competition thus drives the capitalist to transform the organisational and technical condi- 
tions of the labour process through the appropriation of the worker's knowledge.

In this way, the introduction of technological and organisational innovations in the labour process is continuous in the capitalistic mode of production, because it reduces the necessary labour time, as well as the value of the goods and the labour force. In this sense, it is necessary to take into account that the development of science and technology is determined by the logic of capital accumulation and not by the logic of human needs. In the words of Antunes:

[...] living labour, in conjunction with science and technology, is a complex and contradictory unity, under the conditions of capitalist development. [...]Released by the capital to expand, but being in the last instance the prisoner of the need to be subordinated to the imperatives of the process of creation of values, science cannot be converted into primary productive force. (122-123).

Antunes backs on Marx for whom labour process is a capital appreciation process, where main objective is increasing surplus value production. The issue is how capital can increase surplus value production independently of increasing working hours. It is possible through a reduction of working week-the part of time worker needs for own use-and increase in work, corresponding to the capitalist's working hours. Therefore capital will increase working productive force "[...] through changes in ways of working or in working methods or in both" (Marx, 2010: p. 238) and capital appreciation process is established through relative surplus value.

In this way, introduction of technological and organizational innovations in productive process is a constant in capitalist production way, and has no connections with natural, neutral or autonomous issues. The innovation process must be understood within the environment of different social practices, which at the time are the result of class relations in struggle for social control of work in capitalism. It is part of class struggle dynamics, being a political and social control variable. This leads to a complex and contradictory interrelationship between science and value insofar as the potential of science is limited by its class determination (Previtali \& Fagiani, 2015).

As Braverman (1998) already pointed out, the fundamental innovations in production did not come from chemistry, electronics, mechanisation or automation, but from the transformation of science itself into capital; they came from the knowledge of artisans, incorporated into machines built by engineers, in order to obtain the highest efficiency of labour.

Antunes (2013) highlights that social knowledge generated by science has its objective constrained imposed by the logic of the capital, at the same time that occurs unequal appropriation of the results and benefits of science and technology, as well as increasing the productivity of social labour. The author points out that the theory of value acknowledges the growing role of science, but states that, given the subjection of its development to the material base of the relations between capital and labour, it, "[...] cannot, under the capital, become the primary 
productive force in the place of work" (p. 126). Thus, contrary to the idea of the demise of the working class, Antunes explains the changes in the world of labour as part of capital's productive restructuring process.

For Previtali \& Fagiani (2015), the restructuring process can be seen as nothing more than capital restructuring itself to ensure its continuing expansion and accumulation. In this new context, it is possible to modify relationships with the working class through the introduction of a range of flexibilisation processes, including outsourcing and subcontracting of labour, the introduction of temporary work and group work and a series of heavy defeats of the trade union movement that was born when Taylorist-Fordist practices held sway. In a context where the watchwords are 'flexibility' and 'quality', companies have noticed that much of the innovation process, particularly incremental innovations in the labour process, depends on the direct participation of the worker.

Antunes calls that the "phenomenal dimension" (p. 35) the Taylorism/Fordism crisis and the diffusion of new productive models, highlighting the developing of Toyotism. According to the author, the productive restructuring consists of a response from the capital to its destructive logic and its structural determinants, such as the decreasing rate of profit, the workman resistance and the impossibility of capital control, as a societal metabolism oriented towards the expansion and accumulation of capital.

The author states that theory of value recognizes increasing role of science, but he stresses that is hampered in its development by material basis of relations between capital and labour, and cannot become main productive force to substitute labour. According to him, the new productive model implies a greater integration between living labour and dead labour, assuming as consequence the following outline: a) the convergence of living labour into dead labour; b) the reduction of the labour called unproductive, related to the management and supervision activities; $c$ ) the reduction of unproductive times in the labour process; d) the expansion of immaterial labour, which is endowed with greater intellectual dimension in the productive and service sectors. These tendencies occur in different ways as a function of an unevenly distributed capitalist division of labour.

One of the highlights of the book is the exhibition, with great detail, of the productive restructuring in England, in the midst of neoliberal policies and the introduction of Toyotism in the processes of labour. Antunes discourses, relying on dense and rigorous empirical research, about class struggles in that country, with major opposition movements, among which the wave of social explosions of 1989 and 1990 that hit the conservativeness of Thatcher and made the victory of Tony Blair possible with the so called "Third Way". This, in turn, was configured, according to Antunes, as the preservation of what is essential in neoliberalism, therefore, doomed to failure as early as his birth.

From Antunes's point of view, the working class that rises simultaneously, as a result of the class struggle and the inner logic of global capitalism (i.e., the rela- 
tionship between economics and politics), is more comprehensive than the working class from the middle of the last century, being even more complex, more heterogeneous and fragmented than that which prevailed in the golden period of the Taylorist-Fordist system. Disagreeing with those who understand working class as merely the industrial proletariat and reduce productive labour exclusively into the manufacturing universe, the author proposes the notion of class-who-lives-from-labour, by which he seeks to reinvigorate the Marxist concept of class and the particularities of the new social forms of labour relations.

For Antunes (2013), the "class-who-lives-from-labour" relates to all men and women, productive and unproductive, deprived of means of production who are forced to sell their labour power in the countryside and in the city in exchange for wages; namely, industrial and rural proletariat, outsourced, subcontracted and temporary workers, wage earners in the service sector, telemarketing and call center workers, and the unemployed. The author points out that the industrial proletariat is its main core, because it directly produces surplus value. However, capital managers and those living from interest and speculation, small businessmen, small urban bourgeoisie and rural landowner bourgeoisie are excluded, although all of them can be important allies of the working class in the political field.

In this sense, Antunes (2013) throws the challenge of understanding the mosaic of forms that configure the current working class, considering its heterogeneity and its polysemic and multifaceted character. The author indicates the downward trend of the industrial proletariat, stable and specialized, which developed during the Taylorism-Fordism, at the same time that it expands temporary and part-time work in a productive model based on the informational technology integration, in the de-concentration of the productive space and in a horizontal network of production.

New labour relations imposed workers an intense and detailed electronic monitoring through constant analysis of productivity, performance and satisfaction levels among others, introducing workers qualification, and a way of improving its intellectual integration in work. According Fagiani \& Previtali (2014), from the 1990's and especially during current decade, in OECD countries there is an increasing trend of hiring workers in part time, with consequent full time decrease in full time. See down here in Figure 1.

These strategies, corresponding to work and unions controls within class struggle environment, fragment workforce and flatten wages, deregulate labour in name of flexibility and consequently reduce labour rights. The new management toyotist practices enlist the collaboration and involvement of employees by means of individual premium payments. But this element is not new in itself in the field of control of workers and attempts to break class solidarity. The novelty consists in the development of subjective elements that constrain workers to participate in the management of their own work making them, in effect, comanagers of the streamlining of the production process (Previtali \& Fagiani, 2015). 


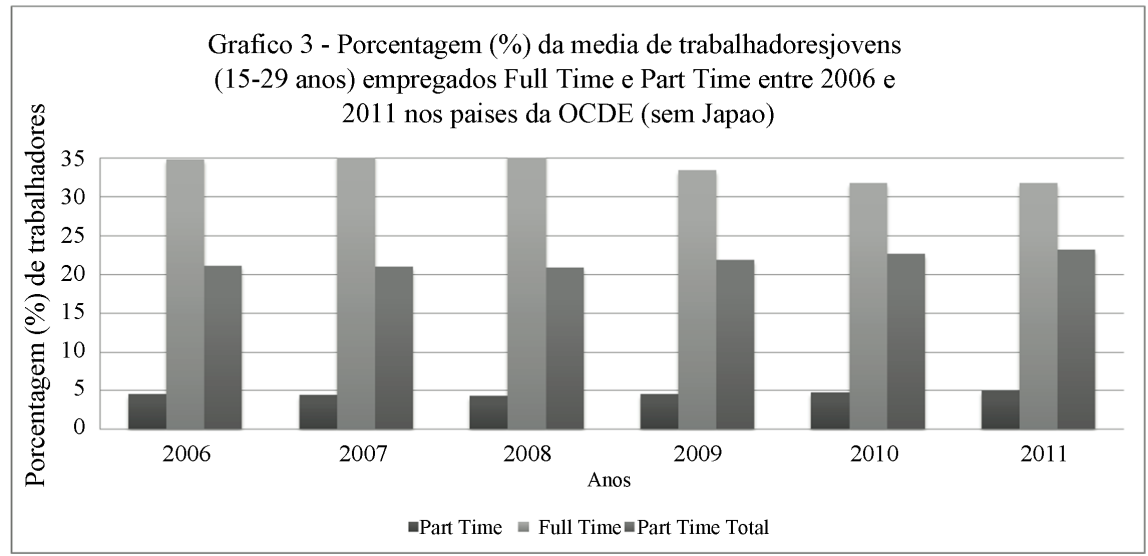

Figure 1. Average Percentage of young workers, between 15 and 29 years, hired full and part time, between 2006 and 2011 in OECD countries, except Japan. Source: Fagiani \& Previtali (2014).

In this context, Antunes draws attention to the new techniques of management of the labour force including the production cells, working in teams and in semi-autonomous groups, the multifunctional labour, more qualified and participatory. For the author, the purpose of these changes is to control the worker's subjectivity with a speech of involvement that, in fact, is a manipulative participation and preserves, in essence, the terms of the alienated and estranged labour.

Either by manual labour exercise, either by immaterial labour, both, how-

ever, controlled by the capital's societal metabolism system, the estrangement (Entfremdung) of the work is, in essence, preserved (p. 132).

Sewell $(1998,2005)$ argues in the same way. To him, there is a limited reintegration between conception and execution in the way that working groups are set up, providing, at best, a merely nominal degree of autonomy to workers. Indeed, the main innovation in Toyotist model is to make such groups responsible for the streamlining and intensification of their own labour. The new management practices enlist the collaboration and involvement of employees by means of individual premium payments.

Antunes (2013: p. 52) points that "the subjectivity that emerges in the workplace is the expression of an inauthentic existence and remains alienated in relation both to what is produced and who produces it". In his view, discourses that refer to the involvement and participation of workers, characteristic of Toyotism, refer to the company's goals. They offer no better working conditions and, much less, imply in overcoming alienation of the work.

\section{Conclusion}

For Antunes (2013), the understanding of contemporary forms of labor value's aggregation is fundamental. Once the surplus value is not extracted only from the material plane of the labour, but also from the immaterial plane, intensifying the conditions of exploitation of the labour force by reducing or even elimi- 
nating unproductive labour. But the author makes a caveat when arguing that the material labour is still prevalent, in relation to the immaterial, especially when analyzing capitalism on a global scale. In the field of labour relations, the author states the tendency towards flexibility, to the outsourced, precarious and unregulated work, highlighting the increase in female labor in many countries.

The author highlights the role of social struggles for the accomplishment of a process of human emancipation, despite the way the working class is forced to be more heterogeneous, complex and fragmented. Arguing that all forms of rebellion are equally important, Antunes makes a caveat, which is that in a commodity-producing society labour revolt takes a statute of centrality and the ecological struggles and the feminist movements acquiring greater vitality just when they are associated with the denunciation of the capital's destructive logic.

At the end of his work, discussing about the relationship between labour, work and freedom, Antunes (2013) underscores the imperative need for elimination of wage labour, the fetishized and estranged labour and the creation of freely associated individuals. But this new social order, endowed with meaning in and out of labour, is linked to the need to fully eliminate the capital and its social metabolism system in all its forms. In the author's words:

In an upper sociability way, the labour, when restructuring the social being, will have unstructured capital. And in this same self-determined work which made meaningless the capital will generate social conditions for the flourishing of an authentic and emancipated subjectivity, giving a new meaning to the work. (p. 184)

It is evident that The Meanings of Work, by Ricardo Antunes, not only represents an instigating theoretical reflection which aims to apprehend the new constituent elements of capital's societal metabolism, but it represents an essential contribution to a project to build a society beyond abstract labour, founded on an authentic freedom. Its reading becomes, thus, crucial to all those committed with the developing of an opposite alternative to the capitalist logic.

\section{Support}

Author Previtali: Researcher CNPq-PQ and Fapemig.

Author Fagiani: Researcher CNPq-Brazil (150243/2017-5). Supervisor: Professor Afrânio Mendes Catani-FEUSP.

\section{References}

Antunes, R. (2013). The Meanings of Work: Essay on the Affirmation and Negation of Work (Vol. 43). Leiden/Boston: Brill Books/Historical Materialism Book Series.

Braverman, H. (1998). Labor and Monopoly Capital: The Degradation of Work in the Twentieth Century. New York: Monthly Review Press.

Carter, B. et al. (2014). They Can't Be the Buffer Any Longer: Front-Line Managers and Class Relations under White Collar Lean Production. Capital \& Class, 38, 323-343. 
http://cnc.sagepub.com/content/38/2/323

Fagiani, C. C., \& Previtali, F. (2014). The Twenty-First Century and a New Working Class Arrangement: Qualification and Precarization. Revista Ciências do Trabalho, 3, 53-67.

Harvey, D. (1992). Condição Pós-Moderna. São Paulo: Edições Loyola.

Harvey, D. (2011). O Enigma do Capital: As crises do capitalismo. São Paulo: Boitempo.

Marx, K. (2010). O Capital (Vol. 1). São Paulo: Boitempo.

Milkman, R., \& Luce, S. (2013). The State of the Unions 2013: A Profile of Organized Labor in New York City, New York State, and the United States. New York: The Joseph S. Murphy Institute for Worker Education and Labor Studies and the Center for Urban Research, CUNY Graduate Center. https://sps.cuny.edu/filestore/8/6/3_bc4b97196c5659e/863_916e1989d05f0e6

Previtali, F. S., \& Fagiani, C. C. (2015). Deskilling and Degradation of Labour in Contemporary Capitalism: The Continuing Relevance of Braverman. Work Organisation, Labour \& Globalisation, 9, 76-91. https://doi.org/10.13169/workorgalaboglob.9.1.0076

Sewell, G. (1998) The Discipline of Teams: The Control of Team-Based Industrial Work through Electronic and Peer Surveillance. Administrative Science Quarterly, 43, 397428. https://doi.org/10.2307/2393857

Sewell, G. (2005). Nice Work? Rethinking Managerial Control in an Era of Knowledge Work, Organization, 12, 685-704.

http://www.uk.sagepub.com/managingandorganizations/downloads/Online\%20articles /ch12/2\%20-\%20

Thompson, P. (2010). The Capitalist Labour Process: Concepts and Connections. Capital \& Class, 34, 7-14.

http://www.izt.uam.mx/sotraem/Bibliografia/Thompsonthecapitalist.pdf

Submit or recommend next manuscript to SCIRP and we will provide best service for you:

Accepting pre-submission inquiries through Email, Facebook, LinkedIn, Twitter, etc. A wide selection of journals (inclusive of 9 subjects, more than 200 journals)

Providing 24-hour high-quality service

User-friendly online submission system

Fair and swift peer-review system

Efficient typesetting and proofreading procedure

Display of the result of downloads and visits, as well as the number of cited articles

Maximum dissemination of your research work

Submit your manuscript at: http://papersubmission.scirp.org/

Or contact ahs@scirp.org 